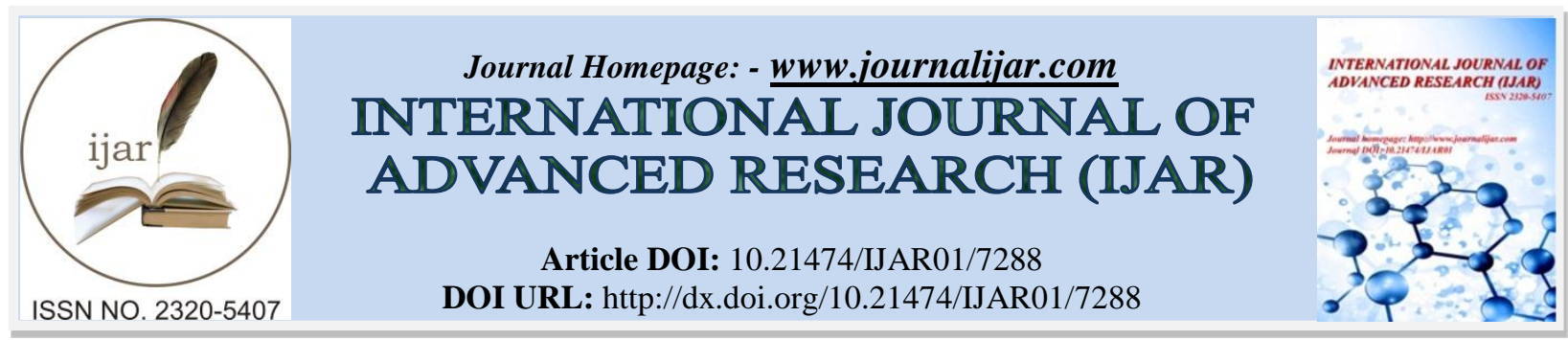

RESEARCH ARTICLE

\title{
ARMY EMPOWERMENT ON AGRICULTURAL PLANT DEVELOPMENT TO SUPPORT NATIONAL FOOD SECURITY SUSTAINABLY IN PUJON, MALANG.
}

1. Master student of brawijaya university.

2. Postgraduate lecturer of brawijaya university.

3. Postgraduate lecturer of wisnu wardhana university.

\section{Manuscript Info}

Manuscript History

Received: 15 April 2018

Final Accepted: 17 May 2018

Published: June 2018

\section{Abstract}

The research purposes of this study are as follows; 1) Analyzing Factors Influencing the Sustainability of National Army from Kodim 0818 in supporting food security in Malang Regency, 2) Creating Soldiers Strategy of National Army from Kodim 0818 in supporting food security in Malang Regency. This research uses descriptiveanalytical method with quantitative approach. This method was chosen to obtain a clear and detailed description of the research issues and the phenomena under study. Thus expected to be constructed a construction which later can be used as model or recommendation material in decision making. The sampling technique used in this study is the total sampling technique because the samples taken are all members of Army from Kodim 0818 Malang who follow National Defence education to improve food security at Pujon as much as 80 people. To obtain data about leadership, communication, reward and motivation and employee performance used data collection method of questionnaire focus assisted by observation, interview technique (interview guide) and documentation technique. While data collection techniques was used Questionnaire, Observation, Documentation and Interview. This research uses qualitative analysis technique with descriptive analysis approach. Meanwhile, to analyze the Sustainability uses Analyzer Structural Equation Modeling (SEM) as a Sustainability measurement Tool.

The results showed that: 1). Factors that affecting Soldiers Sustainability is the natural capital that is the availability of food raw materials both agricultural and livestock and financial capital owned by the community in Pujon district both factors have a positive influence on agricultural sustainability in realizing food security by $80 \%$. 2). Strategy that must be done in the realization of sustainable agriculture is to make food security program in 4 aspects ie in ecology supervise / control the use of chemical fertilizers and assist farmer extension in processing high biogas methane gas. The economic policy undertaken is to assist agricultural extension officers and agricultural agencies in providing insight into obtaining and obtaining capital with light collateral to increase agricultural population and productivity. In the 
institutional dimension where TNI-AD assisted to activate the performance of farmer-livestock groups in Pujon sub-district.

Copy Right, IJAR, 2018,. All rights reserved.

\section{Introduction:-}

\section{Background:-}

It is widely known that efforts to realize food security in Indonesia are currently experiencing many obstacles and problems, especially as food availability is much lower than the number of food demand itself. This is due to the rate of population growth at an interval of 2010-2011 which averaged by $1.49 \%$.

Economic growth in 2015 reached 5.70\%, Increased public purchasing power and changes in people's consumption tastes. Whereas the national food production capacity is relatively slow and even stagnated due to competition in the utilization of land and water resources and stagnant growth of land productivity and decreasing the number of agricultural labor. This imbalance condition encourages food import policy to maintain and improve the national food supply. This is done in order to realize the stability of national food supply.

The law No. 7/1996 on Food, food security is defined as the condition of the fulfillment of food for every community that is reflected in the availability of adequate food, both quantity and quality, safe, equitable, affordable, and based on the diversity of local resources. Food security is a system consisting of subsystems of availability, distribution, and consumption. Food availability subsystem serves to ensure food supply to meet the needs of the entire population, both in terms of quantity, quality, diversity, and safety. The distribution subsystem serves to create an effective and efficient distribution system to ensure that all households can obtain sufficient quantity and quality of food at all times at an affordable price. Subsystem consumption serves to direct the pattern of national food utilization in order to meet the rules of quality, diversity, nutritional content, security, and halal. Based on the definition of food security from FAO (1996) and Law No. 7 of 1996, there are four components that must be met to achieve food security conditions, namely the adequacy of food availability, food availability Stability without fluctuations from season to season or from year to year, Accessibility and affordability to food, and Quality of food safety. Therefore, the need for food in supporting national resilience is an important and strategic commodity for the Indonesian nation considering food is the basic human need which must be fulfilled by government and society. The importance of this food problem demands the strengthening of national food security in order to achieve complete the state resilience.

Pujon Sub-district of Malang Regency is one of the sub-districts in Malang Regency of East Java Province in the case of food supply that is rice, corn, cassava and vegetables major and fruits both at provincial level even up to national level. Army soldiers are seeking to help central and local government to make special efforts in improving food self-sufficiency program through a memorandum of understanding between the Ministry of Agriculture of the Republic of Indonesia and the Chief of Staff of the Armed Forces No. Nota / 01 / MoU / RC.120 / M / 1/2015 which states both sides agreed to cooperate in the agricultural development program by synergizing the potential tasks, authorities and programs that exist in each of the institution. With the memorandum of understanding, Kodim 0818 Malang as the regional unit command as the element of the territorial unit of TNI AD has the obligation to sharpen the special efforts in the realization of food self-sufficiency in Malang Regency through the analysis of the results of last year in order to achieve the successful implementation of the main task to support national food security.

\section{Research purposes:-}

Based on the above background, the research objectives are as follows;

1) Analyzing Factors Influencing Sustainability of Army TNI AD from Kodim 0818 in supporting food security in Malang Regency.

2) Creating Sustainability Strategy of Army TNI AD from Kodim 0818 in supporting food security in Malang Regency.

\section{Research Methods:-}

\section{Time and Location of Research:-}

This research was conducted in Pujon Sub-district, Malang. The main reason for choosing the location is because this institution is one of the sub-districts that conduct the program of TNI AD Territorial Development in order to 
empower the Agriculture sector in order to improve food security. While the time of study was began on July 9, 2017 to October 24, 2017.

\section{Research methods:-}

This research uses descriptive-analytical method with quantitative approach. This method was chosen to obtain a clear and detailed description of the research issues and the phenomena under study. Thus expected to be constructed a construction which later can be used as model or recommendation material in decision making.

\section{Sampling technique:-}

The sampling technique used in this study is the total sampling technique because the samples taken are all members of TNI AD from Kodim 0818 Malang who follow education to defend the state to improve food security in the district Pujon as much as 80 people.

\section{Data Retrieval Techniques:-}

To obtain data about leadership, communication, reward and motivation also employee performance was used data collection method of questionnaire focus assisted by observation, interview technique (interview guide) and documentation technique. While data collection techniques was used Questionnaire, Observation, Documentation and Interview

\section{Data analysis technique:-}

This research uses qualitative analysis technique with descriptive analysis approach. Meanwhile, to analyze the Sustainability Analyzer Structural Equation Modeling (Sem) as a Sustainability Measurement Tool.

\section{Research Result And Discussion:- \\ Data Analysis:- \\ a. Validity Test}

Testing the validity of the data obtained from the instrument in the form of a questionnaire aimed to determine the suitability between the measured tool (questionnaire) and what is measured (statement in the questionnaire) so that the data used for the test results of the instrument used to test the validity of the instrument so that based on the type of its usefulness then the validity can divided into content validity, that is testing based on theoretical basis or the opinion of experts or called face validity, the validity of the criteria is the type of validity that the way of measurement by comparing the correlation value between each item with corrected score by using a method called product correlation technique moment or inter-correlation method Based on the test table discriminant validity outer model by using cross loading above, it can be explained that each indicator has the largest loading value on the variable measured. Thus, from this test it can be concluded that the discriminant validity outer model has been met. Based on the results of statistical data processing using WarpPLS then obtained the results for the validity test consisting of the feasibility of cross loading, discriminant and convergent) obtained results in the following table.

Table 1:- Convergent Validity (Combined Loading and Cross Loading)

\begin{tabular}{|l|l|l|l|l|l|l|l|l|l|}
\hline & $\mathrm{X} 1$ & $\mathrm{X} 2$ & $\mathrm{X} 3$ & $\mathrm{X} 4$ & $\mathrm{X} 5$ & $\mathrm{Y}$ & Type $(\mathrm{a}$ & $\mathrm{SE}$ & $\mathrm{P}$ value \\
\hline $\mathrm{x} 1.1$ & 0.851 & -0.047 & -0.115 & -0.020 & -0.649 & 0.722 & Formati & 0.086 & $<0.001$ \\
\hline $\mathrm{x} 1.2$ & 0.242 & -0.340 & -0.581 & 0.151 & 1.164 & -0.196 & Formati & 0.104 & 0.011 \\
\hline $\mathrm{x} 1.3$ & 0.874 & 0.140 & 0.273 & -0.023 & 0.309 & -0.649 & Formati & 0.086 & $<0.001$ \\
\hline $\mathrm{x} 2.1$ & -0.085 & 0.027 & 0.460 & 0.875 & 0.242 & -1.827 & Formati & 0.111 & 0.404 \\
\hline $\mathrm{x} 2.2$ & -0.121 & 0.811 & 0.401 & -0.063 & 0.313 & 0.300 & Formati & 0.087 & $<0.001$ \\
\hline $\mathrm{x} 2.3$ & 0.124 & 0.813 & -0.415 & 0.034 & -0.320 & -0.238 & Formati & 0.087 & $<0.001$ \\
\hline $\mathrm{x} 3.1$ & -0.120 & 0.716 & 0.738 & 0.548 & 0.016 & -1.570 & Formati & 0.089 & $<0.001$ \\
\hline $\mathrm{x} 3.2$ & 0.059 & -0.144 & -0.292 & 0.876 & 0.970 & -1.569 & Formati & 0.102 & 0.003 \\
\hline $\mathrm{x} 3.3$ & 0.129 & -0.696 & 0.821 & -0.182 & 0.330 & 0.855 & Formati & 0.087 & $<0.001$ \\
\hline $\mathrm{x} 4.1$ & -0.161 & 0.383 & -0.363 & 0.702 & -0.034 & 0.477 & Formati & 0.090 & $<0.001$ \\
\hline $\mathrm{x} 4.2$ & 0.129 & -0.380 & -0.250 & 0.655 & 0.059 & 0.429 & Formati & 0.092 & $<0.001$ \\
\hline $\mathrm{x} 4.3$ & 0.533 & -0.149 & 0.707 & 0.352 & 0.137 & -0.722 & Formati & 0.100 & $<0.001$ \\
\hline $\mathrm{x} 4.4$ & -0.360 & 0.074 & 0.383 & 0.442 & -0.143 & -0.817 & Formati & 0.098 & $<0.001$ \\
\hline $\mathrm{x} 5.1$ & 0.261 & -0.637 & 0.075 & -0.277 & 0.813 & 0.853 & Formati & 0.087 & $<0.001$ \\
\hline $\mathrm{x} .52$ & -0.261 & 0.637 & -0.075 & 0.277 & 0.813 & -0.853 & Formati & 0.087 & $<0.001$ \\
\hline
\end{tabular}




\begin{tabular}{|l|l|l|l|l|l|l|l|l|l|}
\hline $\mathrm{y} 1$ & -0.370 & 0.292 & 0.824 & 1.063 & -0.189 & -0.184 & Formati & 0.106 & 0.043 \\
\hline $\mathrm{y} 2$ & -0.213 & -0.190 & 0.467 & 0.131 & -0.532 & 0.801 & Formati & 0.088 & $<0.001$ \\
\hline $\mathrm{y} 3$ & 0.037 & 1.017 & -0.455 & 0.047 & -0.163 & 0.723 & Formati & 0.090 & $<0.001$ \\
\hline $\mathrm{y} 4$ & 0.091 & -0.636 & 0.128 & 0.067 & 0.611 & 0.833 & Formati & 0.087 & $<0.001$ \\
\hline
\end{tabular}

(Data processed, WarpPLS, January 2018)

Based on the results of validity testing, it is known that the type of validity used in the study is the validity criteria that the value of $p$-value $<0.05$ because of convergent validity required for testing an instrument in the form of questionnaires and for the second condition is the value of loading must be greater than the value of cross loading then discriminant validity is said to be fulfilled. A research can be said to be valid if the research is able to minimize the occurrence of errors and irregularities that may cause a research data bias so that the results are not good even not in accordance with the reference comparison, if the data bias then cannot proceed in the next test step. In data processing using warpPLS in validity table obtained result that p-value value $<0,001$ and loading value $>$ cross loading then research data is said valid.

\section{Reliability Test}

Reliability means that the instruments used in the research should be reliable. In the reliability test there are three types of ways to test the reliability of test retest, alternative-forms and internal consistency. An example of a type of reliability test that uses internal consistency is through the coefficient of Cronbach alpha value, where if the alpha is greater than 0.5 it can be shown that the instrument is reliable (Malhotra, 1992).

Internal consistency test indicator outer structural model is done by calculating composite reliability in each latent variable. The indicator is said to have good internal consistency if the composite reliability value of the latent variable is larger than 0.6 (Ghozali, 2008).

In designing an instrument then the most important correlation test before entering on the analysis activity then the data must be valid and reliable in order to process can be continued on the analysis of warpPLS. In the use of warpPLS software reliability testing has 2 criteria of reliability test with the same type of consistency, among others, composite reliability coefficient and alpha Cronbach coefficient are presented in the following table.

Table 2:- Composite Reliability

\begin{tabular}{|l|l|l|l|l|l|}
\hline $\mathrm{X} 1$ & $\mathrm{X} 2$ & $\mathrm{X} 3$ & $\mathrm{X} 4$ & $\mathrm{X} 5$ & $\mathrm{Y}$ \\
\hline 0.727 & 0.618 & 0.686 & 0.627 & 0.796 & 0.691 \\
\hline
\end{tabular}

(Data processed, WarpPLS, January 2018)

Based on the results of reliability testing with the criteria for composite reliability that the data can be reliable if it is more than 0.6 , so if the value of composite reliability is less than 0.6 then the data was not reliable so that in the process of data analysis will cause bias later. In the table reliability of the figures show more than 0.6 so it can be said reliable, so from this test can be concluded that the indicators of the constituent latent variable has a good internal consistency.

Table .3:- Reliability with Alpha Cronbach

\begin{tabular}{|l|l|l|l|l|l|}
\hline $\mathrm{X} 1$ & $\mathrm{X} 2$ & $\mathrm{X} 3$ & $\mathrm{X} 4$ & $\mathrm{X} 5$ & $\mathrm{Y}$ \\
\hline 0.667 & 0.670 & 0.659 & 0.644 & 0.687 & 0.673 \\
\hline
\end{tabular}

(Data processed, WarpPLS, January 2018)

Based on the results of the processing of reliability using warpPLS obtained results that the number shows more than 0.6 so that the data is said to be reliable.

\section{Testing the Goodness of Fit Structural Model (Inner Model):-}

Goodness of Fit Model in the analysis of warpPLS is an index and measure in assessing good relationship in a correlation between latent variables (inner model). In the fit and quality indices section, we present the results of the three indicators in the model of fit measurements: Average Path Coefficient (APC), Average R-Squared (ARS) and Average Variance Inflation Factor (AVIF) so that an evaluation of a model can be performed. The p-value values for APC and ARS should be less than 0.05 or that the model evaluation is significant. AVIF as a multi-coli nary 
indicator must be smaller than 5 so that with three criteria that have been determined then the output indicates if the goodness of fit model has been met with the value of APC and ARS respectively of 0.210 and ARS 0.801 and significant and the AVIF value of 2.955 has been fulfilled criteria. Testing the Goodness of Fit model is important because the goal is to determine the best model of the existing model (competing model).

Comparison of models is considered very important if the goal as competing models with ARS, AVIF and APC sequence because APC can occur is likely to be lower if there are differences in path coefficient sign. The use of PLS regression method was chosen in this study because there is a non-linear relationship of curve $S$ to know the empowerment of TNI-AD in the development of food crop agriculture to support national sustainable food security in Pujon sub-district.

Table .4:- Output Path Coefficient

\begin{tabular}{|l|l|l|l|l|l|l|}
\hline & $\mathrm{X} 1$ & $\mathrm{X} 2$ & $\mathrm{X} 3$ & $\mathrm{X} 4$ & $\mathrm{X} 5$ & $\mathrm{Y}$ \\
\hline $\mathrm{X} 1$ & & & & & & \\
\hline $\mathrm{X} 2$ & & & & & & \\
\hline $\mathrm{X} 3$ & & & & & & \\
\hline $\mathrm{X} 4$ & & & & & & \\
\hline $\mathrm{X} 5$ & & & & & & \\
\hline $\mathrm{Y}$ & & & & & & \\
\hline
\end{tabular}

(Proceed Data, WarpPLS, Januari 2018)

Tabel 5:- Output P-Values

\begin{tabular}{|l|l|l|l|l|l|l|}
\hline & $\mathrm{X} 1$ & $\mathrm{X} 2$ & $\mathrm{X} 3$ & $\mathrm{X} 4$ & $\mathrm{X} 5$ & $\mathrm{Y}$ \\
\hline $\mathrm{X} 1$ & & & & & & \\
\hline $\mathrm{X} 2$ & & & & & & \\
\hline $\mathrm{X} 3$ & & & & & & \\
\hline $\mathrm{X} 4$ & & & & & & \\
\hline $\mathrm{X} 5$ & & & & & & \\
\hline $\mathrm{Y}$ & 0.338 & 0.004 & 0.190 & 0.149 & $<0.001$ & \\
\hline
\end{tabular}

(Proceed data, WarpPLS, Januari 2018)

Based on the output table coefficient path and p-values output then obtained results that. Output WarpPLS is standardized data so that it can be interpreted the greater the coefficient of the path, the stronger the effect.

\section{Latent Variable Coefficient Output}

In the discussion of goodness of fit in a new model made by the writer as one of the explanatory research activities then calculating the magnitude of the coefficient of determination felt very important, because R-squared goal is to show the percentage of response variables that can be explained by predictor variables, the higher the value the coefficient of determination obtained (close to 1 or 100\%) then the model will be better value and if the model is getting lower (away from 1 or 100\%) then the calculation on the model made can be said to be biased. The result of $\mathrm{R}$-squared calculation is described in the following table.

Table 6:- R-Squared

\begin{tabular}{|l|l|l|l|l|l|}
\hline $\mathrm{X} 1$ & $\mathrm{X} 2$ & $\mathrm{X} 3$ & $\mathrm{X} 4$ & $\mathrm{X} 5$ & $\mathrm{Y}$ \\
\hline & & & & & 0.801 \\
\hline
\end{tabular}

(Data processed, WarpPLS, January 2018)

Based on the output presented in the R-squared table, it is found that the R-squared value or commonly referred to as the coefficient of determination for the empowerment of the Army in the context of the development of food crop agriculture has an influence on sustainable national food security in Pujon by $80 \%$ other variables beyond research and error. The criterion of measurement in the next goodness of fit is to observe the Average Varian Extracted (AVE) value of the objective is to measure the evaluation on convergent validity which has a condition that the value should be> 0.5. AVE output is described in the following table. 
Table 7:- Output AVE

\begin{tabular}{|l|l|l|l|l|l|}
\hline $\mathrm{X} 1$ & $\mathrm{X} 2$ & $\mathrm{X} 3$ & $\mathrm{X} 4$ & $\mathrm{X} 5$ & $\mathrm{Y}$ \\
\hline 0.516 & 0.440 & 0.435 & 0.310 & 0.661 & 0.473 \\
\hline
\end{tabular}

(Data processed, WarpPLS, January 2018)

Based on the Average Output of Extracted variety table it is known that overall response variables and predictor variables observed have an AVE value> 0.5 which means that the variables of empowering the army in the framework of developing food crops to support national food security in a sustainable Pujon district declared has qualified for convergent validity.

The next Goodness of Fit feasibility test is a Full Collinerity VIF which is a full-scale culmination measurement that includes multi-collinality vertically and laterally. The lateral clinically is the cultivation between the latent variable of the predictor and the criterion and can be used to test the common method of bias, the criterion value used in the VIF standard is $<3.3$ and the following is the warpPLS output on the VIF measurement.

Table 8:- Full Collinerity VIF

\begin{tabular}{|l|l|l|l|l|l|}
\hline $\mathrm{X} 1$ & $\mathrm{X} 2$ & $\mathrm{X} 3$ & $\mathrm{X} 4$ & $\mathrm{X} 5$ & $\mathrm{Y}$ \\
\hline 1.532 & 2.496 & 2.294 & 1.442 & 2.259 & 2.727 \\
\hline
\end{tabular}

(Data processed, WarpPLS, January 2018)

Based on the output table Full Collinerity test results obtained that for all variables observed have numbers that are in accordance with the VIF criteria that is $<3.3$ then it can be assumed no multicollinerity (between independent variables should be free).

\section{e. Output Correlations among Latent Variables}

Output Correlations among Latent Variables is the correlation coefficient between variables accompanied by p-value results. These results are needed as an evaluation of the validity of the study instrument's discriminatory. The criterion used is the square root of the AVE value that is the diagonal value and bracketed must be higher than the correlation between the latent variables in the same column. Here is a table Output Correlations among Latent Variables.

Table .9:- Output Correlations among Latent Variables

\begin{tabular}{|l|l|l|l|l|l|l|}
\hline & $\mathrm{X} 1$ & $\mathrm{X} 2$ & $\mathrm{X} 3$ & $\mathrm{X} 4$ & $\mathrm{X} 5$ & $\mathrm{Y}$ \\
\hline $\mathrm{X} 1$ & 0.718 & 0.393 & 0.507 & 0.396 & 0.302 & 0.383 \\
\hline $\mathrm{X} 2$ & 0.393 & 0.663 & 0.636 & 0.366 & 0.791 & 0.820 \\
\hline $\mathrm{X} 3$ & 0.507 & 0.636 & 0.659 & 0.274 & 0.629 & 0.683 \\
\hline X4 & 0.396 & 0.366 & 0.274 & 0.557 & 0.349 & 0.470 \\
\hline X5 & 0.302 & 0.791 & 0.629 & 0.349 & 0.813 & 0.858 \\
\hline
\end{tabular}

(Data processed, WarpPLS, January 2018)

Based on Table Output Correlations among Latent Variabels obtained the result that the validity for the empowerment of TNI-AD in the framework of developing food crops to support sustainable national food security in sub-district Pujon fulfilled because the root value of AVE natural capital and financial capital respectively of 0.820 and 0.858 more great when compared to human capital, social and physical where its position is the response variable and the predictor is taken with the root value of the highest AVE.

Table 10:- $\mathrm{P}$ Values for Correlations

\begin{tabular}{|l|l|l|l|l|l|l|l|}
\hline & & $\mathrm{X} 1$ & $\mathrm{X} 2$ & $\mathrm{X} 3$ & $\mathrm{X} 4$ & $\mathrm{X} 5$ & $\mathrm{Y}$ \\
\hline $\mathrm{X} 1$ & 1.000 & $<0.001$ & $<0.001$ & $<0.001$ & 0.006 & $<0.001$ & \\
\hline $\mathrm{X} 2$ & $<0.001$ & 1.000 & $<0.001$ & $<0.001$ & $<0.001$ & $<0.001$ & \\
\hline $\mathrm{X} 3$ & $<0.001$ & $<0.001$ & 1.000 & 0.014 & $<0.001$ & $<0.001$ & \\
\hline $\mathrm{X} 4$ & $<0.001$ & $<0.001$ & 0.014 & 1.000 & 0.002 & $<0.001$ & \\
\hline $\mathrm{X} 5$ & 0.006 & $<0.001$ & $<0.001$ & 0.002 & 1.000 & $<0.001$ & \\
\hline $\mathrm{Y}$ & $<0.001$ & $<0.001$ & $<0.001$ & $<0.001$ & $<0.001$ & 1.000 & \\
\hline
\end{tabular}


(Data processed, WarpPLS, January 2018)

Based on the output table $\mathrm{p}$ values observed through warpPLS obtained the result that the p-value that shows the value $<0.001$ means the correlation is very strong.

\section{Block Variance Inflation Factors Output}

Output Block Variance Inflation Factors presents the results of vertical collinearity testing that is the predominance of predictor variables. VIF values are presented for each of the criterion variables that indicate the level of cultivation between the independent variables. The criterion is the same as the full collinearity test, which must be $<3.3$ so it can be stated that there is no vertical collinearity problem in the study. VIF values are presented in the following table.

Table 11:- VIF

\begin{tabular}{|l|l|l|l|l|l|}
\hline X1 & X2 & X3 & X4 & X5 & Y \\
\hline 1.532 & 2.496 & 2.294 & 1.442 & 2.259 & 2.727 \\
\hline
\end{tabular}

(Data processed, WarpPLS, January 2018)

Based on the results of data analysis conducted using warpPLS program known that the VIF value in accordance with the criteria of value $<3.3$ so that in this study there is no problem of culinary.

Total Effect and P-Value Total Effect

Total Effect and P-Value Total Effect is one of the requirements used in the analysis to determine the effect of each manifest on the predictor variable to the response variable. The influence in a variable is observed from the p-value value, if $\mathrm{p}<0.001$ then the predictor variable has a significant influence on the response variable, if $p>0,05$ then it means that the predictor variable has no significant effect on the response variable. Based on the results of data analysis using PLS, then obtained the value of Total Effect and P-Value Total Effect as follows.

Table .12:- Total Effect

\begin{tabular}{|l|l|l|l|l|l|l|}
\hline & $\mathrm{X} 1$ & $\mathrm{X} 2$ & $\mathrm{X} 3$ & $\mathrm{X} 4$ & $\mathrm{X} 5$ & $\mathrm{Y}$ \\
\hline $\mathrm{X} 1$ & & & & & & \\
\hline $\mathrm{X} 2$ & & & & & & \\
\hline $\mathrm{X} 3$ & & & & & & \\
\hline $\mathrm{X} 4$ & & & & & & \\
\hline $\mathrm{X} 5$ & & & & & & \\
\hline $\mathrm{Y}$ & & & & & & \\
\hline
\end{tabular}

Source: (Data processed, Warp PLS, January 2018)

Based on the warpPLS output on the total effect it is known that some variables marked bold are predictor variables that have significant influence on the response variable, each latent variable has one manifest variable that has strong influence so that it can represent the latent variable to influence the response variable. The strongest weight in a latent variable can be seen in the attachment for the weight indicator.

Structural Model The influence of the empowerment of the Army in the framework of developing food crops to support sustainable national food security in Pujon sub-district:-

The structural model using Partial Least Square is a modeling of a construct model that aims as the development of a theory owned by the author in developing an existing model, so that PLS-SEM aims to test the predictive relationship between constructs by seeing whether there is a relationship or influence between constructs by looking whether there is a connection or influence between them. The consequence of the use of PLS-SEM is that testing can be done without a strong theoretical basis, ignoring some (non-parametric) assumptions and predictive model prediction parameters seen from the coefficient of determination (R-Square). Therefore, PLS-SEM is very appropriate to use in research that aims to develop the theory. In the SEM method there are several variables called as predictor, response and mediation variables, where the mediation variable is the connecting variable between the predictor variable and the response variable. The mediation variable may change to the response variable if it is influenced by the predictor variable and capable of being a predictor variable if it has an effect on the response variable. 
Mediator variables are also called intervening variables or intermediate variables which theoretically influence observed phenomena (endogenous variables), whose effects must be inference through the effect of the relationship between exogenous variables and their phenomenon. If the exogenous variables no longer have an effect on the endogenous variables after controlling for the mediator variables, a perfect or complete mediation occurs. If the influence of exogenous variables on endogenous variables decreases, but is still different from 0 , after controlling the mediator variable, there is partial mediation (Jogiyanto and Abdillah, 2009).

The reason the authors use warpPLS as a tool in statistical data processing that the approach taken to determine the effect of variables with complexity and many constructs and indicators in the form of recursive that requires a variance approach, so that the weight of each grain can be seen so that the writer knows the value of weighting that is able to represent latent variables as a predictor to influence the response variable. Here is a picture of structural model in research related to Structural Model of TNI-AD empowerment in the framework of development of food crop agriculture to support sustainable national food security in Pujon sub-district.

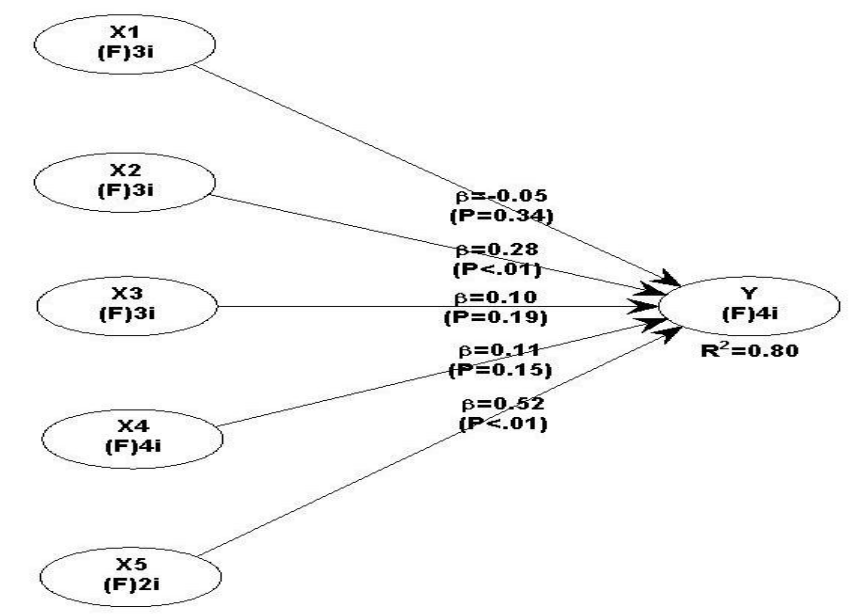

Figure 1:- Interpretation Line

\section{Research Results Implication:-}

Based on data analysis result using WarpPLS 5 it is known that the empowerment of TNI-AD in the framework of development of food crop agriculture to support sustainable national food security in Pujon sub-district represented by agriculture potential and financial impact in the form of nominal amount which becomes profit for farmers in Pujon sub- of $80 \%$ and the rest by other variables outside of research and error.

Based on research result that natural capital give positive influence to food sustainability at Pujon sub district with beta value coefficient 0,277 meaning that every support of natural capital in agricultural land availability criteria to contribute to food sector in Pujon is increasing by $1 \%$ good source of food it is a source of vegetable or animal food will increase the sustainable food security in Pujon sub-district by 0,277 . Efforts made by the Army in food security support activities one of them is to realize the welfare of the community in Pujon which the majority of the population is as farmers and ranchers of the people. It can be seen the magnitude of potential at Pujon in contributing the food sector, the role of the Army to protect the community through several implementation programs, one of which is through community empowerment in realizing food security. Natural problems where agricultural products are commodities derived from biological objects so it depends on the nature of both agricultural commodities and farms.

The farmers understanding is still limited, they only get information that certain seeds are good because the production is better, so without to much thinking, they buy seeds and planting with existing seeds without understanding before about the characteristics of certain seeds that have certain criteria, because not all seedlings can be planted in all types of soil. Certain plants require treatment and a certain place too, so that the seeds planted in places that are not in accordance with the wishes of the type of plant will experience failure or production is not optimal. Another problem is where the decline in production due to the intensity of rainfall is high so that farmers sell agricultural produce at a cheap price. Another problem is limited land. The problem of this land becomes very 
complicated. With the rapid conversion of fertile agricultural land for plantation land, industrial land, real estate, and various other designations, more and more landless farmers. Most of the peasants do not have a certificate of land under control. They only hold girik or something like it, making it difficult for farmers to interact with the banking system. Many abandoned land is controlled by entrepreneurs / conglomerates. This not only causes inequality, but the land becomes unproductive and affects national income issues, such as taxes, employment and so on.

The Existence of Regional Army Command Unit, The Regional Military Command Unit (KOWIL) of the Army under Kodam is the deployment of the defense force of the Army throughout the sovereign territory of the Unitary State of the Republic of Indonesia. KOWIL TNI AD unit serves as a deterrent and initial action against any threats, both coming from within and from abroad. As the eyes and ears of the Army, the KOWIL Unit becomes a listener, sight and recorder of all gestures and foreign infiltration that will endanger the integrity of the nation. The role of the TNI AD KOWIL Unit in the midst of community life so far, can prevent the occurrence of various threats and disruption to national security. The threat of terrorism, radicalism and separatism can be anticipated by the TNI Army KOWIL Unit, thus supporting the national development process proclaimed by the government in a sustainable manner.

The existence of TNI Army KOWIL units ranging from Kodam, Korem, Kodim, Koramil together with Babinsa, is needed by the community, especially in the framework of Military Operation Other Than War (OMSP). Tasks associated with OMSP have a significant portion (there are 14 tasks) when compared to the task on the OMP. Therefore, through the title of OMSP, for example, the role of TNI AD KOWIL Unit whose existence in the areas of food production centers, of course, is very strategic in supporting the increase of national food security. The title of OMSP, prioritized on the TNI Army KOWIL Unit which is located in the areas of food production centers, is carried out in the form of "Teritorial Enchantment" that is through Territorial Development (Binter) with Binwanwil, Binkomsos and Bhakti TNI main methods.

Based on the analysis that financial capital has a positive impact on the sustainability of resiliencefood in Pujon sub district with beta coefficient value of 0,517 which means that the increasing of financial capital either capital of own capital or foreign capital equal to $1 \%$ hence will realize sustainable food security. Financial capital has a positive impact on agricultural sustainability in Pujon sub-district in order to realize food security. So the higher the capital that is owned mainly is the capital itself means that the community is empowered in increasing productivity that becomes the main potential in creating food security in accordance with the potential of the region in Pujon regency. The problem is where the high lending community in dairy cooperatives so many farmers who find it difficult to develop farms and livestock for loan repayment. One factor is the lack of citizen's education in Pujon sub district. So the role of TNI-AD in order to help realize food security is to make the schedule of the implementation of bhakti TNI in agriculture to be implemented in its territory, especially directed to the targeted agricultural location of TNI AD . Danramil moves its members in turns together with farmers, to work together to manage and manage agricultural lands, whether in the form of paddy fields, dry land, tidal / peatlands, lebak, and abandoned land. In this activity can be supported by members of the Army, both from Kodam, Korem and Kodim.Danramil carry out monitoring of the distribution of fertilizer, water, irrigation, and marketing of agricultural products, so as not to harm the farmers. Danramil at certain times participate with Babinsa to move, along with extension agents from the Agriculture Service, to carry out counseling to farmers. Agricultural counseling philosophy, which helps farmers to help themselves, their families, and society that is, empowering farmers to manage their farms in order to improve the welfare of farmers. With reference to the philosophy of agricultural extension, Danramil and Babinsa should carry out participatory agricultural education using adult education principles, as follows: Farmers participate in voluntary counseling, that is, the consciousness and willingness of the peasants to come, any decision-making. Extension materials are based on the needs of farmers, and use simple language so easily accepted by farmers. Babinsa as a counselor must be serious in order to be accepted by the farming community. Because of the potential, desire, ability and ability to advance already existed on the farmers, so that with serious counseling provided by Babinsa will benefit and cause excitement of the farmers to seek. Babinsa as counselor should be equipped with equipment and materials for task implementation. Under certain circumstances, Babinsa participates in working with farmers, will be more impressive and attached to the peasants and become a new habit for farmers. Babinsa in counseling activities must generate confidence in the ability of self, so that will lead to the participation of the farm community is reasonable. 


\section{Conclusions And Suggestions:- \\ Conclusions:-}

1. Factors that affect Sustainability Soldiers are natural capital whether the availability of raw materials of food both agricultural and livestock and financial capital owned by the community in Pujon district both factors have a positive influence on agricultural sustainability in realizing food security by $80 \%$.

2. Strategy that must be done in the realization of sustainable agriculture is to create food security programs in 4 aspects, namely in ecology supervise / control the use of chemical fertilizers and assist farmer extension in processing high biogas methane gas. The economic policy undertaken is to assist agricultural extension officers and agricultural agencies in providing insight into obtaining and obtaining capital with light collateral to increase agricultural population and productivity. In the institutional dimension where TNI-AD assisted to activate the performance of farmer-livestock groups in Pujon sub-district.

\section{Suggestion:-}

It is needed to provide awareness and understanding to all levels of society on the existence and role of TNI AD Kowil Unity, that the existence and role of TNI AD Kowil Unity is very beneficial in helping the government to guard the process of national development in a sustainable manner. Thus, the Army can be an equal partner in addressing every nation's problems, including participating in overcoming food self-sufficiency and national food security

\section{Bibliography:-}

1. Abdurachman, A., A. Darian dan A. Mulyani. 2008. Strategi dan teknologi pengelolaan lahan kering mendukung pengadaan pangan Nasional. Jurnal Litbang Pertanian 27 (2) : 43-49.

2. Basuki, S. 2000. Optimasi pola usaha tumpangsari dengan program tujuan ganda pada areal tanaman pinus. Jurnal Sosial Ekonomi.Vol. I No. 1: 1-15.

3. Budhi, G. S. 2010. Dilema kebijakan dan tantangan pengembangan diversifikasi usahatani tanaman pangan. Analisis Kebijakan Pertanian. Vol. VIII (3). Hal.241-258.

4. Damihartini, R. S. dan A. Jahi. 2005. Hubungan karakteristik petani dengan kompetensi agribisnis pada usahatani sayuran di Kabupaten Kediri, Jawa Timur. Jurnal Penyuluhan. Vol. I No. 1 : 41-48.

5. Edwarsyah, 2010. Analisis Indeks dan Status Keberlanjutan Pengelolaan DAS dan Pesisir Citarum Jawa Barat. Ceureumen 1(1):1-10.

6. Fanani, Z., 2001. Struktur Pendapatan Rumahtangga Petani yang Mengusahakan Sistem Usahatani Terpadu antara Tanaman dengan Sapi Perah di Kecamatan Pujon, Kabupaten Malang. Jurnal Ternak Tropika, 2(2):6269.

7. Hendarto, K. A. 2008. Optimalisasi penggunaan lahan di sub DAS Ambang : pendekatan Analitikal Hirarki Proses dan Goal Programming. JMHT. Vol. XIV (1) : 9-18.

8. Hendayana, R. 2001. Optimalisasi Penggunaan Sumberdaya Rumah Tangga Petani di Daerah Aliran Sungai : Kasus DAS Wawar, Kabupaten Kebumen dan Purworejo, Jawa Tengah . Agro Ekonomi. Vol VIII (2) : 9-28.

9. Hidayah, I. 2010. Integrasi usahatani dan diversifikasi komoditas dalam rangka penanggulangan dampak keterpurukan ekonomi pasca serangan hama kelapa Aspidiotus destructuor di Kecamatan Kei Besar Kabupaten Maluku Tenggara. Agrika. Vol. 4 No. 2 : 70-92.

10. Kastaman, R., D. R. Kendarto, dan A. M. Aji. 2007. Model optimasi pola tanam pada lahan kering di Desa Sarimukti Kecamatan Pasirwangi Kabupaten Garut. Jurnal FTIB. Vol 1 (1) : 1-11.

11. Nurmalina, R., 2008. Analisis Indeks dan Status Keberlanjutan Sistem Ketersediaan Beras di Beberapa Wilayah Indonesia. Jurnal Agro Ekonomi, 26(1):47-49.

12. Pimentel, D., 2005. Environmental and economic costs of the application of pesticides primarily in the United States. Environment, Development, and Sustainability 7:229-252.

13. Rusdiana, O. dan R. R. Ghufrona. 2011. Aplikasi model optimasi linear goals programming dalam menentukan pola penggunaan lahan optimal di DAS Citarum Hulu. Jurnal SilvikulturTropika. Vol. 02 No. 01 : 26-36. 